\title{
Meat quality and fatty acid profile of Brazilian goats subjected to different nutritional treatments
}

\author{
L.S. Lopes ${ }^{a}$, S.R. Martins ${ }^{\text {b }}$, M.L. Chizzotti ${ }^{\text {c,* }}$, K.C. Busato ${ }^{\text {b }}$, I.M. Oliveira ${ }^{\text {c }}$, O.R. Machado Neto ${ }^{\text {a }}$, P.V.R. Paulino ${ }^{\text {c }}$, \\ D.P.D. Lanna ${ }^{\mathrm{d}}$, M.M. Ladeira ${ }^{\mathrm{a}}$
}

a Department of Animal Science, Universidade Federal de Lavras, MG, Brazil

${ }^{\mathrm{b}}$ Department of Animal Science, Universidade Federal do Vale do São Francisco, PE, Brazil

${ }^{c}$ Department of Animal Science, Universidade Federal de Viçosa, MG, Brazil

' Department of Animal Science, Escola Superior de Agricultura "Luiz de Queiroz", MG, Brazil

\section{A R T I C L E I N F O}

\section{Article history:}

Received 8 April 2013

Received in revised form 22 January 2014

Accepted 13 March 2014

Available online 20 March 2014

\section{Keywords:}

Fatty acid profile

Collagen

Goat meat

\begin{abstract}
A B S T R A C T
This study evaluated the effect of feed restriction and goat genotype on meat quality. Three genotypes (Brazilian native breed Canindé; Brazilian native breed Moxotó; and F1 Boer crossbred animals obtained by crossing Boer bucks with local breed does) and three different feeding regimens (ad libitum fed, AL; restricted fed at $75 \%$ of the ad libitum, R.75; or restricted fed at $50 \%$ of the average ad libitum intake, R.50) were used. There was no difference $(P>0.05)$ in chemical composition, total and soluble collagen, and shear force of the Longissimus lumborum muscle among genotypes. However, AL had greater amounts of soluble collagen and crude protein in the muscle $(P<0.05)$ than R.75. No difference $(P>0.05)$ was observed for the myofibrillar fragmentation index. The goat genotype presented few differences in their fatty acid profiles. However, goats fed ad libitum had a more favorable fatty acid profile for human health with greater concentrations of oleic acid, unsaturated fatty acids, and conjugated linoleic acid.
\end{abstract}

(c) 2014 Elsevier Ltd. All rights reserved.

\section{Introduction}

Goat's meat is an important food source in developing countries. The browsing habits and adaptation to harsh climates of goats makes them useful in semi-arid and harsh environmental conditions. Goat meat constitutes one of the main sources of animal protein in the human diet in the semi-arid region of developing countries (Upton, 2004). In Brazil, the northeast herd represents $91 \%$ of the national goat population (IBGE, 2012), and is primarily composed of native, non-descript and crossbred goats (resulting from mating between native, non-descript and also exotic breeds). The dry season in northeast Brazil is long and frequently animals are subjected to feed restriction that could alter their meat characteristics. Moxotó and Canindé are Brazilian native goat breeds that are classified as suitable for meat and hide (Canindé) or meat, hide and milk (Moxotó) production. They are small sized animals (on average 30 to $40 \mathrm{~kg}$ body weight and $55 \mathrm{~cm}$ average height), that are well adapted to semi-arid conditions and feeding restrictions, but are not specialized for meat or milk production, so exotic breeds, notably Boer, have been used in crossbreeding schemes to improve productivity and meat quality.

\footnotetext{
* Corresponding author at: Department of Animal Sciences, Universidade Federal de Viçosa, Viçosa, MG, 36570-000, Brazil. Tel.: + 553138993324.

E-mail address: mariochizzotti@ufv.br (M.L. Chizzotti).
}

Meat sensory attributes such as color, texture, taste and tenderness can be affected by animal age, gender, breed and diet, due to differences in biological characteristics (collagen, fibers, lipids, enzymes, and others) of the muscular tissue (Renand, Picard, Touraille, Berge, \& Lepetit, 2001).

Yáñes et al. (2006, 2007) studied the effect of feed restriction ( $0 \%, 30 \%$ and $60 \%)$ on Saanen goats, and observed that feed restriction reduced carcass weight, while decreasing muscle tissue and fat proportions. Nonetheless, Madruga et al. (2008) reported that feed restriction had no effect on the chemical, physical, and sensory quality of Moxotó and Canindé meat.

The hypothesis for the current study was that different genotypes and restricted feeding levels would lead to a different metabolic status which might impact meat characteristics. Therefore, the objectives were to determine if different feed restriction levels in different goat genotypes affects chemical composition, total collagen content, collagen solubility, tenderness, loss of exudate, color and fatty acid profile of goat meat.

\section{Materials and methods}

\subsection{Animals, diets and experimental design}

The experiment was performed on the Campus of Agricultural Sciences of the Federal University of San Francisco Valley, in Petrolina 
(PE), Brazil. Before the beginning of the trial, animals were allowed to adapt to feed and pens for 30 days, during which all goats were fed the same diet, ad libitum, to decrease the effect of previous nutrition on their performance and body composition.

Three different genotypes, Brazilian native breed Canindé, Brazilian native breed Moxotó, and $\mathrm{F}_{1}$ Boer crossbred animals obtained by crossing Boer bucks with local breed does were used. The animals were subjected to three feeding regimens : ad libitum fed, AL; restricted fed at $75 \%$ of the average ad libitum intake, R.75; or restricted fed at $50 \%$ of the average ad libitum intake, R.50. The amount of feed offered to the restricted fed animals was adjusted every 15 days in order to offer 75 or $50 \%$ of the average feed intake (in $\mathrm{g}$ of $\mathrm{DM} / \mathrm{kg}$ of body weight) of the ad libitum fed animals of the same genotype. Forty-five intact male goats (15 Canindé, 15 Moxotó, and 15 F1 Boer $\times$ local breed), with an average age of 4 months and an initial body weight (BW) of $15 \pm 0.85 \mathrm{~kg}$ were used. Five animals of each genotype (Canindé, Moxotó, or F1 Boer) were randomly assigned to one of three feeding regimens (AL, R.75 or R.50) in a $3 \times 3$ factorial design.

The diet was formulated according to recommendations of National Research Council - NRC (2007) for native goats with daily weight gain of $100 \mathrm{~g}$ (Table 1 ) with a forage:concentrate ratio of 40:60 in the form of a total mixed diet. Clean water was available all the time in plastic buckets. The goats were confined for 100 days and then slaughtered at the Instituto Federal do Sertão Pernambucano (Petrolina, PE, Brazil).

\subsection{Slaughter and sampling procedures}

Before slaughter, final BW was measured as the BW after fasting (12 $\mathrm{h}$ for liquids and $24 \mathrm{~h}$ for solids). The goats were slaughtered using captive bolt stunning followed by cutting carotid arteries and jugular veins. The carcasses were chilled at $4{ }^{\circ} \mathrm{C}$ for $24 \mathrm{~h}$, and the cold carcass weight was measured. Each carcass was split into 2 longitudinal halves. The Longissimus lumborum muscle, between the 10th and 13th ribs of the right half-carcass was removed and dissected into muscle, fat, and bone components. Cross-cuts were performed from the cranial portion and five $2.54 \mathrm{~cm}$ thick steaks were obtained (one for the determination of color, shear force and losses; one for fatty acid profile; one for chemical composition, one for total collagen and collagen solubility; and one for myofibrillar fragmentation index), vacuum-packed and stored at $-20{ }^{\circ} \mathrm{C}$.

\subsection{Chemical and physical analyses}

To determine chemical composition, the steak was placed in a multiprocessor to obtain a homogenous mass, which was subsequently lyophilized and grounded. Crude protein (CP) was quantified according

Table 1

Ingredients and chemical composition of the experimental diet.

\begin{tabular}{|c|c|}
\hline & Composition (\% DM) \\
\hline \multicolumn{2}{|l|}{ Ingredients } \\
\hline Napier grass & 40.0 \\
\hline Ground whole corn & 33.0 \\
\hline Soybean meal & 25.2 \\
\hline Common salt & 0.6 \\
\hline Mineral mix & 1.2 \\
\hline \multicolumn{2}{|l|}{ Nutrients } \\
\hline Dry matter $^{1}$ & 63.1 \\
\hline Crude protein $^{2}$ & 19.2 \\
\hline Ether extract ${ }^{2}$ & 2.2 \\
\hline $\operatorname{Ash}^{2}$ & 7.0 \\
\hline Neutral detergent fiber ${ }^{2}$ & 26.6 \\
\hline Non-fibrous carbohydrates ${ }^{2}$ & 43.5 \\
\hline Indigestible neutral detergent fiber ${ }^{2}$ & 4.7 \\
\hline
\end{tabular}

to the Kjeldahl method and ether extract (EE) was obtained according to the Soxhlet method, the moisture was removed in a dry oven at $105{ }^{\circ} \mathrm{C}$ for $24 \mathrm{~h}$, and the mineral matter (MM) was determined in oven at $550{ }^{\circ} \mathrm{C}$ for $6 \mathrm{~h}$.

To determine the color, the steak was exposed to air for approximately $30 \mathrm{~min}$ and the values of $L^{*}$ (luminosity), $a^{*}$ (intensity of red), and $b^{*}$ (intensity of yellow) were read using a Minolta CR-10 colorimeter, calibrated for a white standard, using illuminant D65 and $10^{\circ}$ observer. Five readings were performed for each sample, and the average values of $L^{*}, a^{*}$, and $b^{*}$ recorded.

For the analysis of the shear force (SF) and loss of exudates during preparation, only the Longissimus lumborum muscle from the goats fed ad libitum was used because the other groups did not have sufficient muscle area for this analysis. The SF was determined using $2.54-\mathrm{cm}$ steak, which had been previously thawed and baked in an electric oven pre-heated to $150{ }^{\circ} \mathrm{C}$ until the internal temperature of the meat reached $71{ }^{\circ} \mathrm{C}$. The monitoring of the internal temperature was performed using a K-type thermometer, whose probes were inserted into the geometric center of each steak. The samples were then cooled overnight in a refrigerator until an internal temperature of 1 to $5{ }^{\circ} \mathrm{C}$ was reached. Five cylinders from each meat sample were removed, in the direction of the muscular fibers, using a sharp, stainless steel $1.27 \mathrm{~cm}$ diameter borer according to Wheeler, Koohmaraie, and Shackelford (1995). The cylinders were sheared perpendicularly using a V-shaped cutting blade attached to a MECMESIN BFG $500 \mathrm{~N}$ model texturometer equipped with a Warner Bratzler style blade to determine the SF in $\mathrm{kgf} / \mathrm{cm}^{2}$.

The quantification of the water loss due to thawing and cooking was performed on the steak used to determine the SF. The loss of water was quantified by weighing the sample before and after thawing. The cooking losses (drip + evaporation) were obtained by weighing the baking pans with and without the samples (AMASA, 1978).

The total collagen $(\mathrm{mg} / \mathrm{g})$ and soluble collagen (\% of the total) were quantified through their hydroxyproline content based on the methodology proposed by Woessner Jr. (1961) and modified by Hadlich, Morales, Silveira, Oliveira, and Chardulo (2006). From a homogenized steak, five grams were removed and placed in plastic tubes with $20 \mathrm{~mL}$ of distilled placed in a water bath for two hours at $80^{\circ} \mathrm{C}$. After cooking, the samples were homogenized for $1 \mathrm{~min}$ in a turrax mixer and centrifuged at $1000 \mathrm{~g}$ for $15 \mathrm{~min}$ at room temperature. The supernatant and sediment fractions were separated into glass tubes and 30 and $50 \mathrm{~mL}$ of $6 \mathrm{M} \mathrm{HCl}$ were added, respectively. The samples were placed in a dry oven at $100{ }^{\circ} \mathrm{C}$ for $16 \mathrm{~h}$ for hydrolysis. The samples were then filtered and diluted $1: 10$ and $1: 25$, and the $\mathrm{pH}$ adjusted to 6.0 with $2 \mathrm{M} \mathrm{NaOH}$. After this procedure, $2.0 \mathrm{~mL}$ of the supernatant and sediment fractions and $1 \mathrm{~mL}$ of the oxidizing solution (10 mL of Chloramine solution T 7\%; $40 \mathrm{~mL}$ of Citrate Buffer) were transferred to the test tubes. After $20 \mathrm{~min}$ at room temperature, $1.0 \mathrm{~mL}$ of color reagent (5 g of 4-dimethylaminobenzaldehyde, $20 \mathrm{~mL}$ of propanol, and $9 \mathrm{~mL}$ of $60 \%$ perchloric acid) was added. The samples were maintained in a water bath for $15 \mathrm{~min}$ at $60^{\circ} \mathrm{C}$. After cooling, their absorbance at $560 \mathrm{~nm}$ was measured (Penfield \& Meyer, 1975).

To determine the myofibrillar fragmentation index (MFI), the steak without fat and connective tissue was homogenized and a $4 \mathrm{~g}$ sample taken. The samples were homogenized in a turrax homogenizer in $40 \mathrm{~mL}$ of MFI buffer (MFIB) at $2{ }^{\circ} \mathrm{C}$ for $30 \mathrm{~s}$. After homogenization, the samples were centrifuged at $1000 \mathrm{~g}$ for $15 \mathrm{~min}$ at $2{ }^{\circ} \mathrm{C}$, and the supernatant was discarded. The pellet was suspended in $40 \mathrm{~mL}$ of MFIB at $2{ }^{\circ} \mathrm{C}$ and homogenized with a glass rod (Culler, Parrish Júnior, Smith, \& Cross, 1978). Then further centrifugation was performed at $1000 \mathrm{~g}$ for 15 min at $2{ }^{\circ} \mathrm{C}$, and the supernatant again discarded. The pellet was then suspended in $10 \mathrm{~mL}$ of MFIB at $2{ }^{\circ} \mathrm{C}$ and homogenized in a vortex and filtered in a polyethylene sieve with approximately $1.0-\mathrm{mm}$ mesh. Ten milliliters of MFIB were added at $2{ }^{\circ} \mathrm{C}$ to wash the centrifuge tube and assist in the filtration, in which the material retained in the sieve was discarded and the extracted material was used for MFI. 
Table 2

Means and standard errors of the means of performance of Moxotó, Canindé, and F1 Boer goats subjected to different nutritional levels (NL).

\begin{tabular}{|c|c|c|c|c|c|c|c|c|c|c|c|c|c|}
\hline & \multicolumn{3}{|c|}{ F1 Boer } & \multicolumn{3}{|c|}{ Canindé } & \multicolumn{3}{|c|}{ Moxotó } & \multirow[t]{2}{*}{ SEM } & \multicolumn{3}{|c|}{ P value } \\
\hline & $\mathrm{AL}$ & R.75 & R.50 & $\mathrm{AL}$ & R.75 & R.50 & $\mathrm{AL}$ & R.75 & R.50 & & B & $\mathrm{NL}$ & $\mathrm{B} * \mathrm{NL}$ \\
\hline IBW & 15.8 & 15.2 & 13.9 & 13.1 & 15.4 & 14.3 & 14.5 & 16.1 & 15.8 & - & - & - & - \\
\hline DMI & $907^{A}$ & $306^{\mathrm{D}}$ & $193^{\mathrm{D}}$ & $707^{\mathrm{B}}$ & $304^{\mathrm{D}}$ & $200^{\mathrm{D}}$ & $549^{C}$ & $301^{\mathrm{D}}$ & $216^{\mathrm{D}}$ & 33.5 & 0.001 & $<.0001$ & $<.0001$ \\
\hline FBW & $33.5^{\mathrm{A}}$ & $16.1^{\mathrm{CD}}$ & $13.9^{\mathrm{D}}$ & $26.5^{\mathrm{AB}}$ & $16.4^{\mathrm{CD}}$ & $14.4^{\mathrm{D}}$ & $23.5^{\mathrm{BC}}$ & $15.3^{\mathrm{CD}}$ & $13.8^{\mathrm{D}}$ & 1.84 & 0.063 & $<.0001$ & 0.050 \\
\hline ADG & $176^{\text {ad }}$ & $10^{\text {bd }}$ & $15^{\text {bd }}$ & $156^{\text {ade }}$ & $32^{\text {bde }}$ & $0^{\text {bde }}$ & $95^{\mathrm{ae}}$ & $-9^{\text {be }}$ & $-18^{\text {be }}$ & 0.02 & 0.003 & $<.0001$ & 0.570 \\
\hline HCW & $16.0^{\mathrm{a}}$ & $6.9^{b}$ & $5.9^{\mathrm{b}}$ & $13.2^{\mathrm{a}}$ & $7.0^{\mathrm{b}}$ & $6.0^{\mathrm{b}}$ & $11.8^{\mathrm{a}}$ & $7.0^{\mathrm{b}}$ & $5.8^{\mathrm{b}}$ & 0.88 & 0.163 & $<.0001$ & 0.096 \\
\hline $\mathrm{CCW}$ & $15.6^{\mathrm{a}}$ & $6.5^{\mathrm{b}}$ & $5.6^{\mathrm{b}}$ & $12.8^{\mathrm{a}}$ & $6.6^{\mathrm{b}}$ & $5.7^{\mathrm{b}}$ & $11.4^{\mathrm{a}}$ & $6.6^{\mathrm{b}}$ & $5.4^{\mathrm{b}}$ & 0.86 & 0.13 & $<.0001$ & 0.084 \\
\hline
\end{tabular}

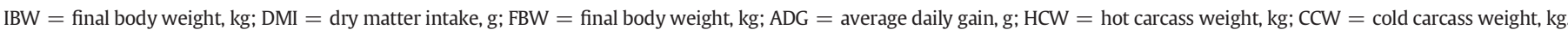
$\mathrm{AL}=$ ad libitum fed; R.75 = restricted fed at 0.75 of ad libitum intake; and R.50 = restricted fed at 0.5 of ad libitum intake.

a,b,c Distinct lowercase letters in the same row, within breed, differ by Tukey's test.

$\mathrm{d}, \mathrm{e}, \mathrm{f}$ Distinct lowercase letters in the same row, within breed, differ by Tukey's test.

$\mathrm{A}, \mathrm{B}, \mathrm{C}, \mathrm{D}$ Distinct capital letters in the same row, differ by Tukey's test.

Subsequently, a $0.25-\mathrm{mL}$ aliquot of the suspended material was removed and deposited in a 100 -mL glass tube. After this procedure, $0.75 \mathrm{~mL}$ of MFIB were added with $4 \mathrm{~mL}$ of biuret reagent to determine the protein content. Simultaneous with the preparation of the samples, standards were prepared with bovine albumin. To determine the MFI, the samples were prepared with MFIB to a final volume of $8 \mathrm{~mL}$ and protein concentration of $0.5 \mathrm{mg} / \mathrm{mL}$. The samples were homogenized and the absorbance read ( $540 \mathrm{~nm})$, and the MFI value was obtained as follows: MFI $=$ absorbance $\times 200$ (Culler et al., 1978).

\subsection{Fatty acid profile}

For the analysis of the fatty acid profile, the steak was thawed at $5{ }^{\circ} \mathrm{C}$ for $12 \mathrm{~h}$ followed by lipid extraction (Folch, Lees, \& Sloane-Stanley, 1957). The fatty acid profile was determined according to Hartman and Lago (1973). A 5-mL sample of lipid extract was concentrated in a water bath at $45^{\circ} \mathrm{C}$ with a gentle nitrogen stream followed by saponification with a solution of $\mathrm{NaOH}$ in $0.5 \mathrm{M}$ methanol and methylation with $\mathrm{NH}_{4} \mathrm{Cl}$, methanol, and $\mathrm{H}_{2} \mathrm{SO}_{4}$. After methylation, $5 \mathrm{~mL}$ of hexane were added, and the solution agitated for $10 \mathrm{~s}$ to separate the esterified fatty acids. Three milliliters of the supernatant fraction (hexane and methylated fatty acids) were then removed and again concentrated in a water bath at $45{ }^{\circ} \mathrm{C}$ with a gentle nitrogen stream. This extract was diluted with $1 \mathrm{~mL}$ of hexane, and $1 \mu \mathrm{L}$ of this solution was injected into a Focus CG-Finnigan model gas chromatograph with a flame ionization detector and a 100-m long, 0.25-mm internal diameter, and $0.20-\mu \mathrm{m}$ thick (Supelco, Bellefonte, PA) CP-Sil 88 capillary column (Varian). Hydrogen at $1.8 \mathrm{~mL} / \mathrm{min}$ was used as the carrier gas. The oven was maintained at $70{ }^{\circ} \mathrm{C}$ for $4 \mathrm{~min}$ and then the temperature was increased, at $13{ }^{\circ} \mathrm{C} / \mathrm{min}$ to $175^{\circ} \mathrm{C}$, which was maintained for $27 \mathrm{~min}$ and then increased at $4{ }^{\circ} \mathrm{C} / \mathrm{min}$ to $215{ }^{\circ} \mathrm{C}$, which was maintained for $9 \mathrm{~min}$, and then increased at $7{ }^{\circ} \mathrm{C} / \mathrm{min}$ to $230^{\circ} \mathrm{C}$, which was

Table 3

Means and standard errors of the means of the chemical composition of the Longissimus lumborum muscle of Moxotó, Canindé, and Boer goats subjected to different nutritional levels (NL).

\begin{tabular}{|c|c|c|c|c|c|c|c|c|c|c|}
\hline \multirow[b]{2}{*}{ (\%) } & \multicolumn{3}{|c|}{ Genetic group } & \multicolumn{3}{|c|}{ Nutritional level } & \multirow[t]{2}{*}{ SEM } & \multicolumn{3}{|c|}{ P value } \\
\hline & C & M & B & $\mathrm{AL}$ & R.75 & R. 50 & & Breed & NL & Breed*NL \\
\hline $\mathrm{CP}$ & 17.1 & 17.8 & 16.7 & $18.1^{\mathrm{a}}$ & $16.9^{\mathrm{ab}}$ & $16.3^{\mathrm{b}}$ & 1.29 & 0.46 & 0.01 & 0.27 \\
\hline MM & 4.7 & 4.8 & 5.0 & 4.8 & 4.6 & 5.0 & 0.55 & 0.23 & 0.23 & 0.99 \\
\hline MOIS & 75.6 & 75.2 & 76.7 & 74.9 & 75.9 & 76.7 & 1.08 & 0.07 & 0.06 & 0.40 \\
\hline $\mathrm{EE}$ & 2.6 & 2.2 & 1.6 & 2.2 & 2.6 & 2.0 & 0.24 & 0.22 & 0.12 & 0.45 \\
\hline
\end{tabular}

a, b, c Different uppercase letters within nutritional level differ by Tukey's test.

$\mathrm{CP}=$ crude protein; $\mathrm{MM}=$ mineral matter; $\mathrm{MOIS}=$ moisture; and $\mathrm{EE}=$ ether extract. $\mathrm{C}=$ Canindé; $\mathrm{M}=$ Moxotó; and $\mathrm{B}=\mathrm{F} 1$ Boer.

$\mathrm{AL}=$ ad libitum fed; $\mathrm{R} .75=$ restricted fed at 0.75 of ad libitum intake; and R.50 $=$ restricted fed at 0.5 of ad libitum intake. maintained for $5 \mathrm{~min}$. The injector temperature was $250{ }^{\circ} \mathrm{C}$, and the detector temperature $300{ }^{\circ} \mathrm{C}$.

Identification of the fatty acids was performed by a comparison of their retention times with standard fatty acids in butter, and the percentage of the fatty acids was obtained through Chromquest 4.1 software (Thermo Electron, Italy).

\subsection{Statistical analysis}

The goats performance and chemical composition, color, total and soluble collagen, myofibrillar fragmentation index and fatty acid profile of the meat were statistically analyzed using the proc GLM of SAS software (1999), in a $3 \times 3$ factorial scheme with three genotypes and three nutritional levels, according to the following model:

$Y_{i j k}=\mu+G_{i}+N_{j}+H \times G_{i j}+\varepsilon_{i j k}$

where $Y_{i j k}$ is the response variable measured in the experimental unit $k$ of the $i$ genotype in the nutritional level $j ; \mu$ is the overall constant; $G_{i}$ is the effect of the $i$ genotype; $N_{j}$ is the effect $j$ nutritional level; $G \times N_{i j}$ is the interaction between the principal effects; $\varepsilon_{i j k}$ is the non-observable random error, presupposed with normal distribution.

The shear force and water losses of the meat of the ad libitum nutritional level were analyzed using the proc GLM of SAS software (1999), according to the following model:

$Y_{i k}=\mu+G_{i}+\varepsilon_{i k}$

where $Y_{i k}$ is the response variable measured in the experimental unit $k$ of the $i$ genotype; $\mu$ is the overall constant; $G_{i}$ is the effect of the $i$ genotype; and $\varepsilon_{i k}$ is the random error.

When significant effects were detected at $\mathrm{P}<0.05$, multiple comparisons of the means were performed, using Tukey's test.

\section{Results and discussion}

\subsection{Chemical and physical analyses}

Dry matter intake and performance are depicted in Table 2 . There was no difference $(P>0.05)$ in the chemical composition of the Longissimus lumborum muscle between the different genotypes (Table 3). Regarding the different nutritional levels, the AL presented greater amounts of $C P$ in the muscle $(P<0.05)$ compared to the goats of the R.50 treatment, which could be partially explained by the higher protein synthesis and rib eye areas in AL.

According to Geay, Bauchart, Hocquette, and Culioli (2001), the main variation in fat content is due to the balance between the energy of the diet and nutritional demands of the goats. However, the greater consumption of energy in AL was not sufficient to increase the percentage intramuscular fat in the Longissimus lumborum muscle. 
Table 4

Means and standard errors of the means of the Longissimus lumborum color characteristics of Moxotó, Canindé, and F1 Boer goats subjected to different nutritional levels.

\begin{tabular}{|c|c|c|c|c|c|c|c|c|c|c|}
\hline & \multicolumn{3}{|c|}{ Genetic group } & \multicolumn{3}{|c|}{ Nutritional level } & \multirow[t]{2}{*}{ SEM } & \multicolumn{3}{|c|}{ P value } \\
\hline & $\mathrm{C}$ & M & B & $\mathrm{AL}$ & R.75 & R.50 & & Breed & NL & Breed $*$ NL \\
\hline$a^{*}$ & 9.36 & 10.50 & 9.34 & $10.65 a$ & 9.57ab & $8.98 b$ & 0.49 & 0.16 & 0.06 & 0.52 \\
\hline$b^{*}$ & $8.28 \mathrm{ab}$ & $8.89 a$ & $7.21 \mathrm{~b}$ & $9.30 \mathrm{~b}$ & $7.82 \mathrm{a}$ & $7.25 \mathrm{a}$ & 0.45 & 0.02 & 0.01 & 0.91 \\
\hline$L^{*}$ & 24.54 & 24.71 & 24.85 & 22.82 & 25.85 & 25.44 & 0.80 & 0.75 & 0.03 & $<0.001$ \\
\hline
\end{tabular}

a, b, c Different uppercase letters within breed or nutritional level, in the same row, differ by Tukey's test.

$\mathrm{C}=$ Canindé; $\mathrm{M}=$ Moxotó; and $\mathrm{B}=\mathrm{F} 1$ Boer.

$\mathrm{AL}=$ ad libitum fed; $\mathrm{R} .75=$ restricted fed at 0.75 of ad libitum intake; and R.50 = restricted fed at 0.5 of ad libitum intake.

There was no difference in the redness $\left(a^{*}\right)$ of the meat between breeds $(\mathrm{P}>0.05)$. The meat of the AL treatment displayed greater values of $a^{*}$ when compared to that of goats of the R.50 $(\mathrm{P}<0.05)$; however, the meat of R.75 displayed $a^{*}$ values similar to those of the other nutritional levels $(\mathrm{P}>0.05)$.

The yellowness $\left(b^{*}\right)$ did not differ among nutritional levels $(\mathrm{P}>0.05)$. The meat of $\mathrm{F}_{1}$ Boer goats had smaller values of $b^{*}$ in relation to Moxotó goats $(\mathrm{P}<0.05)$, and Canindé goats displayed $b^{*}$ values similar to those of the other genotypes $(\mathrm{P}>0.05)$ (Table 3$)$.

There was an interaction between the genotype and nutritional level $(\mathrm{P}<0.05)$ for $L^{*}$. The meat of $F_{1}$ Boer goats fed ad libitum displayed lower values of $L^{*}$. Monte, Selaive-Villarroel, Garruti, Zapata, and Borges (2007) also reported lower $L^{*}$ values for $F_{1}$ Boer crossbreeds than for Anglo-Nubian crossbred goats. The greater the values of $L^{*}$, the paler the meat, and this is related to the final pH, the muscular fiber structure, and the onset of rigor mortis (Albertí et al., 2005).

According to Dhanda, Taylor, and Murray (2003), genetics may influence the color of meat due to differences in pigment deposition in the muscular and adipose tissues and different proportions of muscle fiber types, which would explain the differences in the values of $L^{*}$ between the genotypes in this study. However, Oman, Waldron, Griffin, and Savell (2000) observed, through sensory analysis that the breed did not influence the color of lamb meat during storage.

There was no difference between the breeds for total and soluble collagen $(P>0.05)$. However, a greater amount of soluble collagen was observed in AL than the other nutritional levels. Similar to the total collagen, no difference was observed in the myofibrillar fragmentation index (MFI) $(\mathrm{P}>0.05)$ (Table 4).

According to Hadlich et al. (2006), connective tissue is a fundamental element of organisms and exerts a structural function as an aggregator and support for cells. This function occurs because collagen, which is a fibrous protein endowed with great tensile strength is distributed among nearly all organs. The effect of collagen on the texture of meat is influenced by the cross-links, which make the collagen molecule less soluble and compromise the tenderness of the meat in older animals.

The greater amounts of soluble collagen in the meat of goats fed ad libitum was consistent with Harper (1999), who stated that the weight gain rate influences the meat's tenderness; greater weight gains in less time promote meat with a greater amount of soluble, less stable collagen with fewer covalent cross-links between the collagen fibers.
There was no difference $(P>0.05)$ for the SF and thawing, drip, evaporation, and cooking water losses among the different genotypes (Table 5). The SF values were below the limit of $4.5 \mathrm{kgf}$ for meat to be characterized as tender (Shackelford, Wheeler, \& Koohmaraie, 1997), which confirms the tenderness observed through the evaluation of the MFI for goats fed ad libitum.

In addition to the color, the released juice is one of the greatest determining factors for consumers purchasing meat and is a factor mainly associated with succulence. The water-holding capacity is the power of the meat to retain water during the application of external forces, mainly with the loss of water, fat, and ions during cooking. The water-holding capacity may be determined by several factors, including post-mortem glycolysis, $\mathrm{pH}$, and cooling of the carcass. In addition, the intramuscular fat content may interfere in the water retention, loosening the muscular microstructure and consequently retaining a greater amount of water. The amount of intramuscular and subcutaneous fats that provide protection against dehydration could explain the low water loss values in the animals.

\subsection{Fatty acid profile}

There was a difference among the breeds in relation to the fatty acid profile in the Longissimus lumborum muscle $(\mathrm{P}<0.05)$. The muscles of $\mathrm{F}_{1}$ Boer goats presented greater $(\mathrm{P}<0.05)$ amounts of capric, arachidonic, and docosahexaenoic fatty acids when compared to Canindé goats but no difference compared to Moxotó goats $(\mathrm{P}>0.05)$. Myristoleic fatty acids were present in greater concentrations $(\mathrm{P}<0.05)$ in the meat of F1 Boer goats compared to Moxotó goats. The meat of Canindé and Moxotó goats displayed greater concentrations of heptadecanoic fatty acid compared to $\mathrm{F}_{1}$ Boer goats (Table 6).

The fatty acids observed in the greatest concentrations in the goat meat, regardless of the genotype, were stearic and oleic acids. A high concentration of oleic acid in the intramuscular fat of goats has been reported (Banskalieva, Sahlu, \& Goetsch, 2000). Oleic acid in its cis form is hypocholesterolemic and represents approximately $88 \%$ of the mono-unsaturated fatty acids (MUFA). It acts to reduce LDL and maintain HDL, and is related to the prevention of cardiac diseases (Melton, Amiri, Davis, \& Backus, 1982). In addition, F1 Boer goats had greater amounts of arachidonic and docosahexaenoic fatty acids in their meat.

The meat of Canindé and Moxotó goats displayed greater concentrations of margaric acid $(\mathrm{C} 17: 0)$ compared to $\mathrm{F}_{1}$ Boer goats $(\mathrm{P}<0.05)$.

Table 5

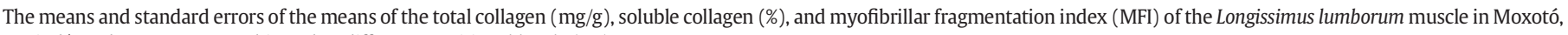
Canindé, and $\mathrm{F}_{1}$ Boer goats subjected to different nutritional levels (NL).

\begin{tabular}{|c|c|c|c|c|c|c|c|c|c|c|}
\hline & \multicolumn{3}{|c|}{ Genetic group } & \multicolumn{3}{|c|}{ Nutritional level } & \multirow[t]{2}{*}{ SEM } & \multicolumn{3}{|c|}{ P value } \\
\hline & C & M & B & $\mathrm{AL}$ & R.75 & R.50 & & Breed & NL & Breed $* \mathrm{NL}$ \\
\hline Total collagen & 1.85 & 2.08 & 2.02 & 1.77 & 2.02 & 2.16 & 0.42 & 0.31 & 0.66 & 0.61 \\
\hline Soluble collagen & 10.81 & 13.15 & 13.32 & $15.21^{\mathrm{a}}$ & $11.65^{\mathrm{b}}$ & $10.41^{b}$ & 2.42 & 0.37 & 0.03 & 0.12 \\
\hline MFI & 83.50 & 84.01 & 74.98 & 81.88 & 80.40 & 80.21 & 8.94 & 0.46 & 0.99 & 0.92 \\
\hline
\end{tabular}

a, b, c Different uppercase letters differ by Tukey's test.

$\mathrm{C}=$ Canindé; $\mathrm{M}=$ Moxotó; and $\mathrm{B}=\mathrm{F} 1$ Boer.

$\mathrm{AL}=$ ad libitum fed; $\mathrm{R} .75=$ restricted fed at 0.75 of ad libitum intake; and R.50 = restricted fed at 0.5 of ad libitum intake. 
Table 6

Means and standard errors of the means of shear force (SF) and water losses in the Longissimus lumborum muscle of Moxotó, Canindé, and $\mathrm{F}_{1}$ Boer goats.

\begin{tabular}{|c|c|c|c|c|c|}
\hline \multirow[t]{2}{*}{ Variable } & \multicolumn{3}{|c|}{ Genetic group } & \multirow[t]{2}{*}{$P$ value } & \multirow[t]{2}{*}{ SEM } \\
\hline & $\mathrm{C}$ & M & B & & \\
\hline Shear force $\left(\mathrm{kgf} / \mathrm{cm}^{2}\right)$ & 2.61 & 2.77 & 2.54 & 0.893 & 0.33 \\
\hline \multicolumn{6}{|l|}{ Water losses (\%) } \\
\hline Thawing & 2.93 & 1.30 & 2.32 & 0.434 & 0.74 \\
\hline Dripping & 2.02 & 1.15 & 2.04 & 0.667 & 0.64 \\
\hline Evaporation & 16.24 & 17.03 & 17.91 & 0.697 & 1.36 \\
\hline Cooking & 18.26 & 18.18 & 19.95 & 0.694 & 1.55 \\
\hline
\end{tabular}

$\mathrm{C}=$ Canindé; $\mathrm{M}=$ Moxotó; and $\mathrm{B}=\mathrm{F} 1$ Boer.

There was no difference $(\mathrm{P}>0.05)$ between genotypes in relation to the total of odd- and branched-chain fatty acids (C13:0; C15:0; C15:0 iso; $\mathrm{C} 15: 0$ anteiso; $\mathrm{C} 17: 0 ; \mathrm{C} 17: 0$ iso, and $\mathrm{C} 17: 1)$ in the meat $(4.6 \%, 4.8 \%$, and 4.3 for the Canindé, Moxotó, and $\mathrm{F}_{1}$ Boer, respectively).

Regardless of the breed used, goat meat displayed a fatty acid profile that is beneficial to health due to the high concentrations of oleic acid, the presence of essential fatty acids, and low concentrations of lauric, myristic, and palmitic acids when compared to the meats of other species.

When the effect of different nutritional levels on the fatty acid profile was analyzed, a larger change was observed in relation to the different genotypes. With the exception of tridecylic and margaric acids (C13:0 and C17:0, respectively), the AL treatment displayed greater concentrations for all odd- and branched-chain fatty acids (C15:0, C15: iso, C15:0 anteiso; $\mathrm{C} 17: 0$ iso, and $\mathrm{C} 17: 1)$ in the meat $(\mathrm{P}<0.05)$ compared to R.50 and R.75 goats (Table 7). The summations of odd- and branched-chain fatty acids for the AL, R.75 and R.50 were $5.81 \%, 4.28 \%$, and $3.67 \%$, respectively. The experimental diet consisted only of fresh forage and concentrate, and according to Wu, Ohajuruka, and Palmiquist (1991), insignificant odd-numbered fatty acids occur in products of plant origin. Therefore, the odd-numbered fatty acids present in the meat originated from rumen microorganisms. The greater concentrations of odd- and branched-chain fatty acids observed in the AL may be due to the greater consumption of TDN by this group $(0.61,0.34$, and $0.24 \mathrm{~kg}$ of TDN/day for the AL, R.75 and R.50, respectively).

The meat of goats from R.50 had greater $(\mathrm{P}<0.05)$ concentrations of myristoleic acid (C14:1 cis9) in relation to the other groups. When the C14:0, C16:0, C18:0, C14:1 cis-9, C16:1 cis-9, and C18:1 cis-9 acids were analyzed as a group, the result suggested that the activity of delta-9 desaturase was more effective in the AL. The meat of the goats fed ad libitum displayed greater amounts of oleic acid and both isomers of conjugated linoleic acid (CLA, cis-9 trans-11 and trans-11 cis-15) $(\mathrm{P}<0.05)$. The greater values of oleic acid $(\mathrm{C} 18: 1)$ may be attributed to the greater animal biosynthesis from stearic acid (C18:0) (Rule, Macneil, \& Short, 1997). Therefore, nutritional strategies that increase the conversion of stearic acid into oleic acid contribute to an improvement in meat quality.

As it was not possible to separate the isomers C18:1 trans-9, trans -10 , and trans- 11 , there was no way of attributing the formation of CLA in the meat to the presence of vaccenic acid. Therefore, a hypothesis for the greater CLA values observed in AL would be that the higher intake, which would allow a greater rate of passage of food through the rumen and less exposure of the fatty acids to rumen bacteria allows intermediate compounds of biohydrogenation to escape and be absorbed in the small intestine.

According to Jenkins, Wallace, Moate, and Mosley (2008), the greater amount of starch consumed by goats fed ad libitum favors the development of protozoa, which are an important source of polyunsaturated fatty acids (PUFA) and CLA to be incorporated into the meat, since the values observed for CLA in the protozoa were 3 to 8 times greater than observed in the bacteria.

There was a decrease in the concentrations of lauric acid (C12:0) $(\mathrm{P}<0.05)$ in the meat as the nutritional levels increased in the diet. There is evidence that this fatty acid, in addition to myristic (14:0) and palmitic (16:0) fatty acids, are fats associated with an increase in blood cholesterol and increase the concentration of LDL due to interference in the LDL hepatic receptors (Woollett, Spady, \& Dietschy, 1992).

Table 7

Means and standard errors of the means of the c of Moxotó, Canindé, and F1 Boer goat meat subjected to different nutritional levels (NL).

\begin{tabular}{|c|c|c|c|c|c|c|c|c|c|c|}
\hline \multirow[b]{2}{*}{ Fatty acid } & \multicolumn{3}{|l|}{ Breed } & \multicolumn{3}{|c|}{ Nutritional level } & \multirow[t]{2}{*}{ SEM } & \multicolumn{3}{|l|}{ P value } \\
\hline & $\mathrm{C}$ & M & B & $\mathrm{AL}$ & R.75 & R.50 & & Breed & NL & Breed $* \mathrm{NL}$ \\
\hline C10:0 & 0.10 & 0.11 & 0.13 & 0.10 & 0.13 & 0.12 & 0.001 & 0.16 & 0.06 & 0.85 \\
\hline C12:0 & 0.14 & 0.14 & 0.17 & $0.12 b$ & $0.14 \mathrm{ab}$ & $0.19 a$ & 0.021 & 0.58 & 0.08 & 0.48 \\
\hline C13:0 & 0.10 & 0.10 & 0.08 & 0.07 & 0.06 & 0.15 & 0.035 & 0.89 & 0.18 & 0.75 \\
\hline C14:0 & 2.48 & 2.50 & 2.73 & 2.50 & 2.52 & 2.69 & 0.202 & 0.47 & 0.80 & 0.06 \\
\hline C14:1 c9 & 0.17 & 0.12 & 0.19 & $0.05 c$ & $0.08 \mathrm{~b}$ & $0.11 \mathrm{a}$ & 0.018 & 0.06 & 0.01 & 0.11 \\
\hline $\mathrm{C} 15: 0$ & 0.80 & 0.87 & 0.81 & $1.06 a$ & $0.72 b$ & $0.70 \mathrm{a}$ & 0.034 & 0.34 & $<0.001$ & 0.13 \\
\hline $\mathrm{C} 15: 0$ iso & 0.32 & 0.33 & 0.35 & $0.42 \mathrm{a}$ & $0.31 b$ & $0.27 \mathrm{~b}$ & 0.022 & 0.63 & $<0.001$ & 0.06 \\
\hline C15:0 anteiso & 0.63 & 0.75 & 0.73 & $1.11 \mathrm{a}$ & $0.60 \mathrm{~b}$ & $0.41 b$ & 0.10 & 0.71 & $<0.001$ & 0.44 \\
\hline $\mathrm{C} 16: 0$ & 22.05 & 22.14 & 21.30 & 21.08 & 22.28 & 22.12 & 0.491 & 0.58 & 0.17 & 0.05 \\
\hline C16:1 c9 & 1.17 & 1.02 & 1.18 & $1.53 \mathrm{a}$ & $1.03 \mathrm{~b}$ & $0.81 \mathrm{c}$ & 0.075 & 0.71 & $<0.001$ & 0.82 \\
\hline C17:0 & $1.70 a$ & $1.74 a$ & $1.30 \mathrm{~b}$ & 1.66 & 1.65 & 1.43 & 0.081 & $<0.001$ & 0.10 & 0.66 \\
\hline $\mathrm{C} 17: 0$ iso & 0.07 & 0.06 & 0.04 & $0.09 a$ & $0.04 \mathrm{~b}$ & $0.04 \mathrm{~b}$ & 0.008 & 0.09 & 0.001 & 0.45 \\
\hline $\mathrm{C} 17: 1$ & 1.040 & 0.950 & 1.004 & 1.400a & $0.907 b$ & $0.687 \mathrm{c}$ & 0.070 & 0.78 & $<0.001$ & 0.51 \\
\hline C18:0 & 22.91 & 24.70 & 22.94 & 19.90b & $25.90 a$ & $24.76 a$ & 1.004 & 0.63 & $<0.001$ & 0.94 \\
\hline C18:1 19 & 33.03 & 30.81 & 31.76 & $40.48 a$ & $30.78 b$ & $24.35 c$ & 1.147 & 0.88 & $<0.001$ & 0.97 \\
\hline $\mathrm{C} 18: 1 t 10, t 11 \mathrm{e} t 12$ & 0.96 & 1.20 & 1.19 & $0.78 \mathrm{~b}$ & $1.25 \mathrm{a}$ & $1.31 \mathrm{a}$ & 0.102 & 0.24 & 0.001 & 0.51 \\
\hline $\mathrm{C} 18: 2 c 9 t 11$ & 0.26 & 0.21 & 0.26 & $0.30 \mathrm{a}$ & $0.23 b$ & $0.22 \mathrm{~b}$ & 0.025 & 0.40 & 0.05 & 0.28 \\
\hline C18:2 c9 c12 & 2.06 & 2.68 & 2.13 & $1.80 \mathrm{~b}$ & $2.05 \mathrm{~b}$ & $3.021 \mathrm{a}$ & 0.219 & 0.09 & 0.003 & 0.97 \\
\hline $\mathrm{C} 18: 2$ t11 c15 & 0.06 & 0.05 & 0.07 & $0.07 a$ & $0.05 b$ & $0.05 \mathrm{~b}$ & 0.004 & 0.07 & 0.002 & 0.06 \\
\hline $\mathrm{C} 18: 3 c 9 c 12 c 15$ & 0.16 & 0.17 & 0.18 & $0.13 b$ & $0.15 b$ & $0.24 a$ & 0.011 & 0.51 & $<0.001$ & 0.91 \\
\hline $\mathrm{C} 18: 3$ c6 c9 c12 & 0.02 & 0.02 & 0.02 & $0.01 \mathrm{~b}$ & $0.02 \mathrm{~b}$ & $0.03 a$ & 0.003 & 0.79 & 0.003 & 0.09 \\
\hline C20:4 & $0.47 \mathrm{~b}$ & $0.85 \mathrm{ab}$ & $1.15 \mathrm{a}$ & $0.43 b$ & $0.74 \mathrm{ab}$ & $1.31 \mathrm{a}$ & 0.173 & 0.04 & 0.01 & 0.89 \\
\hline $\mathrm{C} 20: 5$ & 0.11 & 0.15 & 0.16 & $0.04 b$ & $0.11 b$ & $0.27 \mathrm{a}$ & 0.036 & 0.50 & $<0.001$ & 0.33 \\
\hline $\mathrm{C} 22: 5$ & 0.36 & 0.46 & 0.58 & $0.13 b$ & $0.34 \mathrm{~b}$ & $0.92 \mathrm{a}$ & 0.99 & 0.40 & $<0.001$ & 0.07 \\
\hline C22:6 & 0.05 & 0.08 & 0.09 & $0.02 \mathrm{~b}$ & $0.04 b$ & $0.16 a$ & 0.017 & 0.25 & $<0.001$ & 0.26 \\
\hline
\end{tabular}

a, b, c Different uppercase letters within breed or nutritional level, in the same row, differ by Tukey's test.

$\mathrm{C}=$ Canindé; $\mathrm{M}=$ Moxotó; and $\mathrm{B}=\mathrm{F} 1$ Boer.

$\mathrm{AL}=$ ad libitum fed; R.75 = restricted fed at 0.75 of ad libitum intake; and R.50 = restricted fed at 0.5 of ad libitum intake. 
Table 8

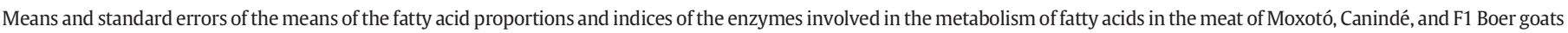
subjected to different nutritional levels (NL).

\begin{tabular}{|c|c|c|c|c|c|c|c|c|c|c|}
\hline & \multicolumn{3}{|l|}{ Breed } & \multicolumn{3}{|c|}{ Nutritional level } & \multirow[t]{2}{*}{ SEM } & \multicolumn{3}{|c|}{ P value } \\
\hline & C & M & B & $\mathrm{AL}$ & R.75 & R.50 & & Breed & NL & Breed $* \mathrm{NL}$ \\
\hline Saturated & 52.3 & 54.2 & 51.5 & $47.5 b$ & $54.8 \mathrm{a}$ & $55.6 a$ & 1.25 & 0.48 & $<0.001$ & 0.56 \\
\hline Unsaturated & 42.1 & 40.6 & 40.4 & $48.6 a$ & $39.9 b$ & $34.5 c$ & 0.99 & 0.55 & $<0.001$ & 0.38 \\
\hline Monounsaturated & 38.9 & 36.0 & 37.2 & $45.6 a$ & $36.4 b$ & $30.2 c$ & 1.08 & 0.38 & $<0.001$ & 0.77 \\
\hline Polyunsaturated & $2.99 b$ & 4.69a & $3.33 b$ & $3.03 b$ & 3.61ab & 4.39a & 0.42 & 0.03 & 0.01 & 0.71 \\
\hline$\omega-6$ & 2.62 & 3.38 & 2.59 & $2.13 b$ & $3.06 a$ & $3.41 \mathrm{a}$ & 0.27 & 0.27 & 0.03 & 0.32 \\
\hline$\omega-3$ & $0.92 b$ & $1.88 \mathrm{a}$ & $1.40 \mathrm{ab}$ & $0.75 b$ & $1.24 b$ & $2.20 \mathrm{a}$ & 0.21 & 0.02 & $<0.001$ & 0.48 \\
\hline$\omega-6 / \omega-3$ & 3.26 & 2.79 & 2.62 & $3.94 a$ & $3.04 b$ & $1.70 \mathrm{c}$ & 0.28 & 0.27 & $<0.001$ & 0.48 \\
\hline
\end{tabular}

a, b, c Different uppercase letters within breed or nutritional level, in the same row differ by Tukey's test.

$\mathrm{C}=$ Canindé; $\mathrm{M}=$ Moxotó; and $\mathrm{B}=\mathrm{F} 1$ Boer.

$\mathrm{AL}=$ ad libitum fed; R.75 = restricted fed at 0.75 of ad libitum intake; and R.50 = restricted fed at 0.5 of ad libitum intake.

However, greater concentrations $(\mathrm{P}<0.05)$ for all MUFA, with the exception of arachidonic acid (C20:4), was observed in R.50 compared to AL and R.75. The greater MUFA concentrations observed in R.50 is in accordance with Rule et al. (1997). According to these authors, as the de novo synthesis of fatty acids increases, the MUFA present in the muscle is diluted.

The meat of Moxotó goats displayed a greater concentration of MUFA when compared to the other breeds $(\mathrm{P}<0.05)$ and a greater concentration of $\omega-3$ series fatty acids $(\mathrm{P}<0.05)$ compared to the meat of Canindé goats but no difference compared to $\mathrm{F}_{1}$ Boer goats $(\mathrm{P}>0.05)$ (Table 8$)$.

The meat of goats fed ad libitum displayed a concentration of fatty acids that is better for human health in relation to the other nutritional levels. The AL treatment displayed lower concentrations of SFA $(P<0.05)$ and greater concentrations of UFA $(P<0.05)$. Similarly, AL treatment displayed greater concentrations of MUFA $(P<0.05)$ compared to other feeding levels and lower concentrations of PUFA ( $\mathrm{P}<0.05$ ) compared to R.50 (Table 8).

A likely explanation for the aforementioned values would be the lower biohydrogenation of fatty acids in the rumen, which allows for increased escape of fatty acids and, consequently, a greater absorption of unsaturated fatty acids in the small intestine. In addition, AL goats produced more fatty acids through de novo synthesis (mainly oleic acid), which diluted the concentrations of MUFA.

A lower concentrations of $\omega-3$ and $\omega-6$ series fatty acids was found in AL when compared R.50, because of the dilution of fatty acids. However, according to Enser et al. (1990), three factors should be taken into account when the nutritional value of food fat is assessed: the total lipid content, the unsaturated:saturated fatty acid ratio, which should be greater than 0.4 , and the $\omega 6: \omega 3$ ratio, which should be less than 4 . Therefore, the meat from the three nutritional levels fit within the values proposed by these authors.

Another possible explanation for the lower concentration of $\omega-3$ and $\omega-6$ series fatty acids displayed by the goats fed ad libitum, in addition to the effect caused by dilution, would be the greater activity of the desaturase enzymes that convert linoleic and linolenic acids into fatty acids with more than 20 carbons and the action of the elongase enzyme, which promotes the addition of 2 carbons in the fatty acid structure (Malau-Aduli, Siebert, Bottema, \& Pitchford, 1997).

Approximately $70 \%$ of the fat was in the form of stearic acid, MUFA, and PUFA and is therefore not a fat source that potentially causes cardiovascular diseases in humans. In addition, oleic acid was the fatty acid observed in the greatest amount and this fatty acid can increase HDL blood levels.

\section{Conclusion}

The different goat genotypes displayed small differences in the quality of their meat and fatty acid profiles. However, the goats fed ad libitum displayed better quality meat due to the lower amounts of soluble collagen and a more favorable fatty acid profile for human health with greater concentrations of oleic acids, unsaturated fatty acids, and CLAs.

\section{References}

Albertí, P., Panea, B., Ripoll, G., Sañudo, C., Ollleta, J. L., Hegueruella, I., Campo, M. M., \& Serra, X. (2005). Estandarización de las metodologías para evaluar la calidad del producto (animal vivo, canal, carne, grasa) en los rumiantes. In INIA (Ed.), Medición del color (pp. 216-225). Madrid: INIA.

AMASA (1978). Guidelines for cooking sensory evaluation of meat. (Chicago).

Banskalieva, V., Sahlu, T., \& Goetsch, A. L. (2000). Fatty acid composition of goat muscles and fat depots: A review. Small Ruminant Research, 37, 255-268.

Culler, R. D., Parrish Júnior, F. C., Smith, G. C. \& Cross, H. R. (1978). Relationship of myofibril fragmentation index to certain chemical physical and sensory characteristics of bovine Longissimus muscle. Journal of Food Science, 43, 1177-1180.

Dhanda, J. S., Taylor, D. G., \& Murray, P. J. (2003). Growth, carcass and meat quality parameters of male goats: Effects of genotype and live weight at slaughter. Small Ruminant Research, 50, 57-66.

Enser, M., Scollan, N. D., Choi, N. J., Kurt, E., Hallet, K., \& Wood, J. D. (1990). Effects of dietary lipid on the content of conjugated linoleic acid (CLA) in beef cattle muscle. Journal of Animal Science, 69, 143-146.

Folch, J., Lees, M., \& Sloane-Stanley, G. H. (1957). A simple method for the isolation and purification of total lipids from animal tissue. Journal of Biological Chemistry, 226, 497-509.

Geay, Y., Bauchart, D., Hocquette, J., \& Culioli, J. (2001). Effect of nutrition factors on biochemical, structural and metabolic characteristics of muscles in ruminants, consequences on dietetic value an sensorial qualities of meat. Reproduction, Nutrition, Development, 41, 1-26.

Hadlich, J. C., Morales, D. C., Silveira, A. C., Oliveira, H. N., \& Chardulo, L. A. L. (2006). Efeito do colágeno na maciez da carne de bovinos de distintos grupos genéticos. Acta Scientiarum Animal Science, 28, 57-62.

Harper, G. S. (1999). Trends in skeletal muscle biology and the understanding of toughness in beef. Australian Journal of Agricultural Research, 50, 1105-1129.

Hartman, N. L., \& Lago, R. C. (1973). A rapid preparation of fatty acid methyl esters from lipids. Laboratory Practice, London, 22, 475-476.

IBGE (2012). www.ibge.gov.br (Accessed 18.12.13).

Jenkins, T. C., Wallace, R. J., Moate, P. J., \& Mosley, E. E. (2008). Recent advances in bio hydrogenation of unsaturated fatty acids within the rumen microbial ecosystem. Journal of Animal Science, Champaign, 86, 397-412.

Madruga, M. S., Torres, T. S., Carvalho, F. F., Queiroga, R. C., Narain, N., Garrutti, D., Souza Neto, M. A., Mattos, C. W., \& Costa, R. G. (2008). Meat quality of Moxotó and Canindé goats as affected by two levels of feeding. Meat Science, 80, 1019-1023.

Malau-Aduli, A. E. O., Siebert, B. D., Bottema, C. D. K., \& Pitchford, W. S. (1997). A comparison of the fatty acid composition of triacylglycerol in adipose tissue from Limousin and Jersey cattle. Australian Journal of Agricultural Research, 48, 715-722.

Melton, S. L., Amiri, M., Davis, G. W., \& Backus, W. R. (1982). Flavor and chemical characteristics of ground beef form grass-, forage-grain- and grain-finished steers. Journal of Animal Science, 55, 77-87.

Monte, A. L. S., Selaive-Villarroel, A. B., Garruti, D. S., Zapata, J. F. F., \& Borges, A. S. (2007). Parâmetros físicos e sensoriais de qualidade da carne de cabritos mestiços de diferentes grupos genéticos. Ciência e Tecnologia dos Alimentos, 7, 233-238.

National Research Council - NRC (2007). Nutrient requirements of small ruminants: Sheep, goats, cervids, and new world camelids. Washington: National Academic Press (384 pp.).

Oman, J. S., Waldron, D. F., Griffin, D. B., \& Savell, J. W. (2000). Carcass traits and retail display-life of chops from different goat breed types. Journal of Animal Science, 78, 1262-1266.

Penfield, M. P., \& Meyer, B. H. (1975). Changes in tenderness and collagen of beef semitendinosus muscle heated at two rates. Journal of Food Science, 40, 150-154.

Renand, G., Picard, B., Touraille, C., Berge, P., \& Lepetit, J. (2001). Relationship between muscle characteristics and meat quality traits of young Charolais bulls. Meat Science, 59, 49-60. 
Rule, D. C., Macneil, M. D., \& Short, R. E. (1997). Influence of sire growth potential time on feed, and growing-finishing strategy on cholesterol and fatty acids of ground carcass and longissimus muscle of beef steers. Journal of Animal Science, 75, 1525-1533.

Shackelford, S. D., Wheeler, T. L., \& Koohmaraie, M. (1997). Tenderness classification of beef: I. evaluation of beef longissimus shear force at 1 or 2 days postmortem as a predictor of aged beef tenderness. Journal of Animal Science, 75, 2417-2422.

Upton, M. (2004). The role of livestock in economic development and poverty reduction. Pro-poor livestock policy initiative. Working paper, 10, Rome: FAO (57 pp.)

Wheeler, T. L., Koohmaraie, M., \& Shackelford, S. D. (1995). Standardized WarnerBratzler shear force procedures for meat tenderness measurement. Clay Center: R.L. Hruska ( 7 pp.).

Woessner, J. F., Jr. (1961). The determination of hydroxyproline in tissue and protein samples containing small proportions of this imino acid. Archives of Biochemistry and Biophysics, 93(2), 440-447.
Woollett, A. L., Spady, K. D., \& Dietschy, M. J. (1992). Saturated and unsaturated fatty acids independently regulate low-density lipoprotein receptor activity and production rate. Journal of Lipid Research, 33, 77-88.

Wu, Z., Ohajuruka, O. A., \& Palmiquist, D. L. (1991). Ruminal Synthesis, bio hydrogenation, and digestibility of fatty acids by dairy cows. Journal of Dairy Science, 74, 3025-3034.

Yáñes, E. A., Resende, K. T., Ferreira, A. C. D., Medeiros, A. N., Silva Sobrinho, A. G., \& Artoni, S. M. B. (2007). Effects of feed restriction on yield, retail cuts and tissue composition of carcass of Saanen kids. Brazilian Journal of Animal Science, 36(3), 666-673.

Yáñes, E. A., Resende, K. T., Ferreira, A. C. D., Pereira Filho, J. M., Silva Sobrinho, A. G., Teixeira, I. A. M. A., \& Medeiros, A. N. (2006). Feed restriction in goats: Carcass yield, commercial cuts, and carcass composition. Brazilian Journal of Animal Science, 35(5), 2093-2100. 